\title{
An EP4 Receptor Agonist Prevents Indomethacin-Induced Closure of Rat Ductus Arteriosus In Vivo
}

\author{
HIROKI KAJINO, TAKANOBU TANIGUCHI, KENJI FUJIEDA, FUMITAKA USHIKUBI, AND \\ IKUNOBU MURAMATSU \\ Department of Pediatrics [H.K., K.F.], Department of Biochemistry [T.T.], Department of Pharmacology \\ [F.U.], Asahikawa Medical College, Asahikawa 078-8510, Japan, and Department of Pharmacology \\ [I.M.], Fukui Medical University, Fukui 910-1193, Japan
}

\begin{abstract}
Indomethacin exerts a strong tocolytic effect by suppressing uterine contractions mediated by prostaglandins. However, indomethacin also induces in utero closure of fetal ductus arteriosus (DA), leading to serious neonatal consequences. Using rats, we tested the effect of an agonist for a subtype of prostaglandin E2 receptor (EP4), ONO-AE1-437 and its prodrug ONO-4819, as a DA dilator during indomethacin treatment. In vitro, ONO-AE1437 exhibited a potent dilatory effect on DA against $\mathrm{O}_{2}$ - and indomethacin-induced contractions in a concentration-dependent manner. In vivo, rat dams were given indomethacin $(10 \mathrm{mg} / \mathrm{kg}$, p.o.) alone or with ONO-4819 $(0.3 \mu \mathrm{g} / \mathrm{kg} / \mathrm{h}$, s.c. $)$ on $\mathrm{d} 21$ of gestation and pups were delivered $4 \mathrm{~h}$ later through cesarean section to evaluate the ratio of diameter of DA to that of pulmonary artery. Pups from dams with no drug had DA/PA ratio of $0.9 \pm 0.05$, whereas those from dams with indomethacin alone
\end{abstract}

ABSTRACT

had a decreased ratio of $0.2 \pm 0.03$. When ONO-4819 was co-administered to the dams, the ratio recovered significantly to $0.7 \pm 0.06$. The administration of ONO-4819 to the dams did not induce any increase in the uterine activity. These results suggest that administration of an EP4 agonist in addition to indomethacin might prevent adverse reactions of indomethacin on fetal DA without restricting its tocolytic effects. (Pediatr Res 56: 586590, 2004)
Abbreviations
COX, cyclooxygenase (EC 1.14.99.1)
DA, ductus arteriosus
NSAID, nonsteroidal antiinflammatory drugs
PA, pulmonary artery
PG, prostaglandin

In the late gestational period, $\mathrm{PG}$ play key roles in the physiologic processes leading to labor. In the mother, PG are key players in the initiation and progression of parturition $(1,2)$, whereas in the fetus they participate in the regulation of circulatory change at birth. In this regulation, the closure of the DA is a critical event (3). DA functions in utero as a shunt vessel that connects the PA and the systemic circulation, bypassing the unexpanded fetal lungs. After birth, the DA closes rapidly as pulmonary circulation is established. The fetal DA is normally maintained patent by dilators, of which $\mathrm{PGE}_{2}$ is a major mediator that is supplied mainly by the placenta (3). At birth, the increase in oxygen tension along with the drop in $\mathrm{PGE}_{2}$ level in neonatal circulation, which follow initiation of

Received June 16, 2003; accepted April 23, 2004.

Correspondence: Takanobu Taniguchi, M.D., Ph.D., Department of Biochemistry, Asahikawa Medical College, Midorigaokahigashi, Asahikawa, 078-8510 Japan; e-mail: takotago@asahikawa-med.ac.jp

Supported by a Grant-in-Aid for Scientific Research from the Ministry of Education, Science, Sports and Culture of Japan, by a grant from the Smoking Research Foundation of Japan, and by a grant from the Ono Cancer Research Foundation.

DOI: 10.1203/01.PDR.0000139409.25014.35 pulmonary respiration and placental segregation, respectively, result in postnatal closure of DA (3). Four subtypes of $\mathrm{PGE}_{2}$ receptor have been identified, designated EP1, EP2, EP3, and EP4 (4). Although the distribution of PG receptors shows variation among species, EP4 has been shown to be a primary receptor subtype of $\mathrm{PGE}_{2}$ at fetal DA in several mammals (5-7). In the case of humans, data are available only at neonatal DA in which EP4 is also a major receptor subtype of $\mathrm{PGE}_{2}(8)$. Mice lacking EP4 gene died of patent DA soon after birth $(9,10)$, implying an additional function of EP4 as a sensor of circulating $\mathrm{PGE}_{2}$ to prepare DA closure after birth.

Indomethacin is an NSAID that suppresses prostanoid synthesis by inhibiting COX. In the context of preterm labor, there is some controversy as to whether NSAID are a useful therapeutic choice, despite their tocolytic effect, because morbid neonatal events such as respiratory distress syndrome, necrotizing enterocolitis, and intraventricular hemorrhage may follow their administration (11). One of the established phenomena during NSAID-induced tocolysis is DA closure in utero; this impairs the pulmonary function after birth by forcing a large amount of blood flow through unexpanded fetal lung 
(12-14). In this study, we have tested a selective EP4 agonist as a DA dilator during indomethacin tocolysis using near-term pregnant rats.

\section{METHODS}

Animals. We followed the guidelines produced by the ethical committee of our institutes, which conform with the U.S. National Institutes of Health Guide for the Care and Use of Laboratory Animals. Female Wistar rats, 10-12 wk old, were mated individually under free access to the usual diet and water. The day on which a vaginal plug was found was designated as $\mathrm{d} 0$ of gestation.

In vitro study. Immediately after full-term cesarean delivery, pups were decapitated and soaked in ice-cold Krebs-Henseleit solution (composition in $\mathrm{mM}: \mathrm{NaCl} 112, \mathrm{KCl} 5.9, \mathrm{MgCl}_{2}$ 1.2, $\mathrm{CaCl}_{2} 2, \mathrm{NaHCO}_{3} 25, \mathrm{NaH}_{2} \mathrm{PO}_{4} 1.2$, and glucose 11.5) gassed with $5 \% \mathrm{CO}_{2} / 95 \% \mathrm{~N}_{2}$. The thorax was opened to excise the heart and major vessels en bloc under a dissecting microscope. Then, DA was dissected out to obtain a DA ring using fine tweezers. These operations were done in ice-cold KrebsHenseleit solution gassed with $5 \% \mathrm{CO}_{2} / 95 \% \mathrm{~N}_{2}$. The specimen was carefully mounted between two stainless steel wires $(0.1$ $\mathrm{mm}$ diameter) in an assay chamber of a Micro Easy Magnus UC-5A (UFER Medical Instrument, Kyoto, Japan), basically as described previously $(15,16)$. The chamber was filled with Krebs-Henseleit solution, which was continuously gassed with $5 \% \mathrm{CO}_{2} / 95 \% \mathrm{~N}_{2}$ at $37^{\circ} \mathrm{C}$. A resting tension of $1 \mathrm{mN}$ was initially applied and the responses were recorded isometrically through force displacement transducers (T7-8-240, Orientec, Tokyo, Japan). In preliminary experiments, we had confirmed that the resting tension is optimal because $60 \mathrm{mM} \mathrm{KCl}$ produced a maximum contraction (data not shown). All preparations were equilibrated for $60 \mathrm{~min}$, followed by a test contraction with $60 \mathrm{mM} \mathrm{KCl}$. Samples were then exposed either to 5\% $\mathrm{CO}_{2} / 95 \% \mathrm{O}_{2}$ or to $10 \mu \mathrm{M}$ indomethacin under an atmosphere of $5 \% \mathrm{CO}_{2} / 95 \% \mathrm{~N}_{2}$. When the contraction of DA reached a plateau, ONO-AE1-437 was added in the chamber in a cumulative manner. At the end of each experiment, samples were dilated by the addition of $0.1 \mathrm{mM}$ papaverine to obtain the zero tension value.

In vivo study. At $1600 \mathrm{~h}$ on d 20 of gestation, an osmotic pump (ALZET Micro-Osmotic Pump, model 1003 D, DURECT Corp., Cupertino, CA) containing either saline alone or saline plus ONO-4819 was implanted subcutaneously in the dams. At $0900 \mathrm{~h}$ on d 21, either $2 \mathrm{~mL}$ of $1 \%$ methyl cellulose alone or $2 \mathrm{~mL}$ of $1 \%$ methyl cellulose plus indomethacin (10 $\mathrm{mg} / \mathrm{kg}$ body weight) was administered through an orogastric tube. After pups were obtained by cesarean delivery, they were rinsed quickly in a warm water bath and placed in a humidified chamber at $37^{\circ} \mathrm{C}$ for $10 \mathrm{~min}$. The living pups were frozen either immediately or $3 \mathrm{~h}$ after birth using whole-body freezing method (17). The frozen thorax was sliced in $10-\mu \mathrm{m}$ thicknesses on a cryomicrotome in the frontal plane, and the inner diameters of the common PA and the DA were measured every 10 slices in $8-15$ planes. The narrowest diameter of each vessel was used to determine the DA/PA ratio.
Uterine activity. On d 20 of gestation, a balloon connected to a polyethylene catheter was inserted through a laparotomy into the right uterine horn of the dams after removing one fetus under urethane anesthesia $(1.2 \mathrm{~g} / \mathrm{kg}$ body weight, s.c.). The intrauterine pressure was recorded with a pressure transducer (MPU-0.5A, Nihon Kohden, Tokyo, Japan). After the uterine motility became stabilized, ONO-4819 in saline was administered through a catheter placed in the right internal jugular vein using a syringe pump. The uterine activity in Montevideo units (18) was assessed every $10 \mathrm{~min}$. The values were expressed as percentages, taking the unit value in the 10 -min period just before the start of the drug infusion as $100 \%$.

Data analysis. Values were presented as means \pm SEM. Statistical significance was tested in a one-way ANOVA and Fisher's exact probability test, and a $p$ value $<0.01$ was considered to be significant. Concentration-response data for ONO-AE1-437-induced relaxations were analyzed with the Prism computer program (GraphPad Software, San Diego, CA).

Materials. Indomethacin, methyl cellulose, papaverine, urethane, oxytocin, and $\mathrm{PGF}_{2 \alpha}$ were obtained from Wako Chemicals (Osaka, Japan). Two EP4 agonists, ONO-AE1-437 and ONO-4819 (19), a prodrug of ONO-AE1-437, were provided by ONO Pharmaceutical Company (Osaka, Japan); both were dissolved initially in ethanol then diluted in saline.

\section{RESULTS}

\section{DA contraction in vitro and the effect of EP4 agonist.} Representative recordings for $\mathrm{O}_{2}$ - and indomethacin-induced DA contraction are shown in Figure 1, $a$ and $b$, respectively. The DA constriction by indomethacin is slower and less prominent than that by $\mathrm{O}_{2}$. This result is in agreement with the previous reports $(20,21)$, supporting the notion that circulating $\mathrm{PGE}_{2}$ rather than locally released $\mathrm{PGE}_{2}$ works dominantly as a DA dilator. ONO-AE1-437 reversed both DA contractions in a concentration-dependent manner. The $\mathrm{pEC}_{50}$ values of the relaxation responses of the DA are $9.4 \pm 0.2$ and $9.2 \pm 0.1$ for $\mathrm{O}_{2^{-}}$and indomethacin-induced DA contractions, respectively (Fig. 2). These are in good agreement with the affinity values reported in the binding experiments (19).

DA contraction in vivo and the effect of EP4 agonist. Next, we tested the effect of ONO-4819 in vivo, on indomethacininduced DA contraction in utero and on neonatal DA closure after birth.

Representative photographs of DA section are shown in Figure 3 and the results are summarized in Figure 4. Administration of indomethacin $(10 \mathrm{mg} / \mathrm{kg}$ body weight $)$ induced DA contraction in utero (DA/PA ratio was $0.2 \pm 0.03$ with indomethacin and $0.9 \pm 0.05$ without), which was reversed significantly by co-administration of ONO-4819 (DA/PA ratio was $0.7 \pm 0.06$ and $0.8 \pm 0.08$, for 0.3 and $3 \mu \mathrm{g} / \mathrm{kg}$ body weight $/ \mathrm{h}$, respectively). In addition, administration of a large dose of ONO-4819 (3 $\mu \mathrm{g} / \mathrm{kg}$ body weight $/ \mathrm{h})$ did not affect DA closure after birth.

Uterine activity in vivo and the effect of EP4 agonist. Finally, we tested the effect of ONO-4819 on uterine activity 

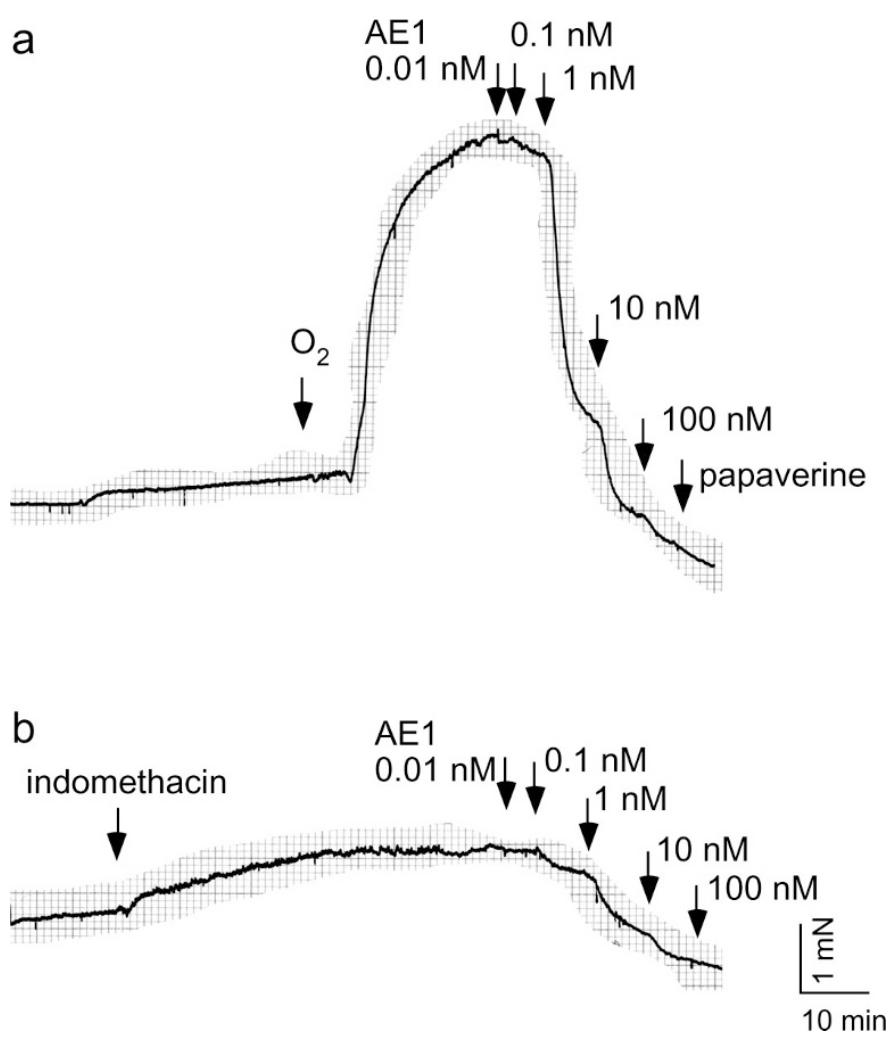

Figure 1. Relaxation effects of ONO-AE1-437 on DA in vitro. Representative recordings of ONO-AE1-437-induced relaxation of DA precontracted by $\mathrm{O}_{2}$ (a) or indomethacin $10 \mu \mathrm{M}(b)$ are shown. The bubbling gas was switched from $\mathrm{N}_{2}$ to $\mathrm{O}_{2}$ as indicated. After DA contraction became stable, ONO-AE1437 was added in a chamber cumulatively from $0.01 \mathrm{nM}$ to $100 \mathrm{nM}$. At the end of all experiments, relaxation with $0.1 \mathrm{mM}$ papaverine was tested. Scales are the same in all charts, as shown at bottom right.

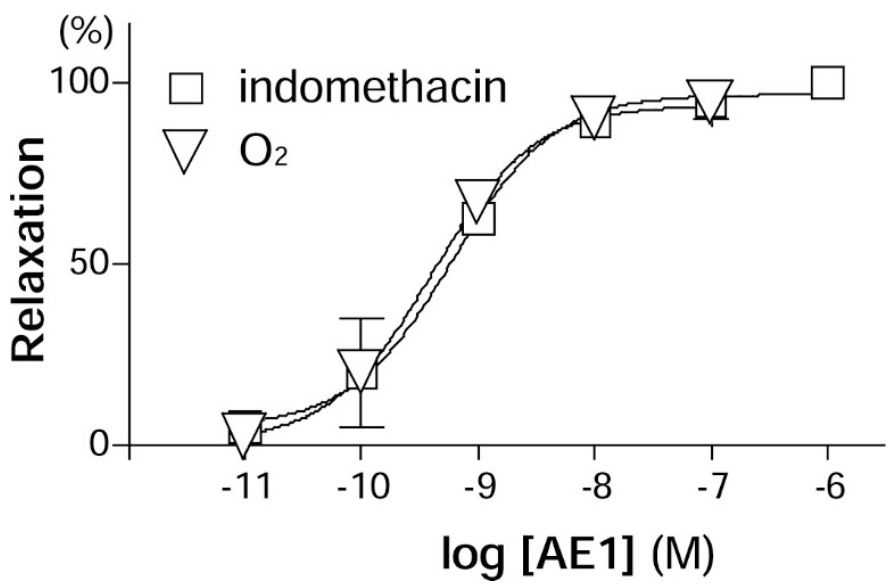

Figure 2. Concentration-dependent relaxation of DA in vitro by ONO-AE1437 administration. Relaxation of DA precontracted by $\mathrm{O}_{2}$ (triangle) or by indomethacin $10 \mu \mathrm{M}$ (square) was studied with cumulative addition of ONOAE1-437 (0.01-100 nM). In each case, data were obtained from two independent experiments.

because this is a critical issue in estimating the applicability of EP4 agonists in tocolysis.

No parturition was observed in the dams that received ONO-4819. Moreover, as shown in Table 1, ONO-4819 did not induce any increase in uterine activity, even at a high dose $(3 \mu \mathrm{g} / \mathrm{kg} / \mathrm{h})$. These findings are consistent with the observation
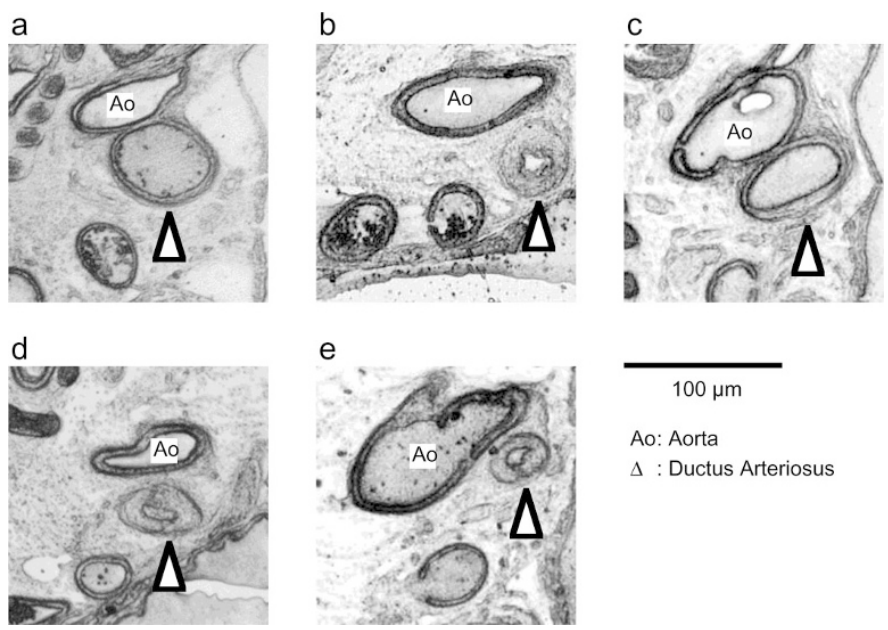

Figure 3. Morphology of DA in vivo. Photographs of representative cases are shown. Rat pups were born from dams that were treated with s.c. saline alone $(a, d)$, s.c. saline plus p.o. indomethacin $10 \mathrm{mg} / \mathrm{kg}$ body weight $(b)$, s.c. ONO-4819 $0.3 \mu \mathrm{g} / \mathrm{kg}$ body weight/h plus p.o. indomethacin $(c)$, or s.c. ONO-4819 $3 \mu \mathrm{g} / \mathrm{kg}$ body weight $/ \mathrm{h}$ plus p.o. indomethacin $(e)$. Pups were examined for DA closure at $0 \mathrm{~h}(a, b, c)$ or $3 \mathrm{~h}(d, e)$ after birth as described in "Methods." Aorta $(A o)$ and DA (arrowheads) are indicated.

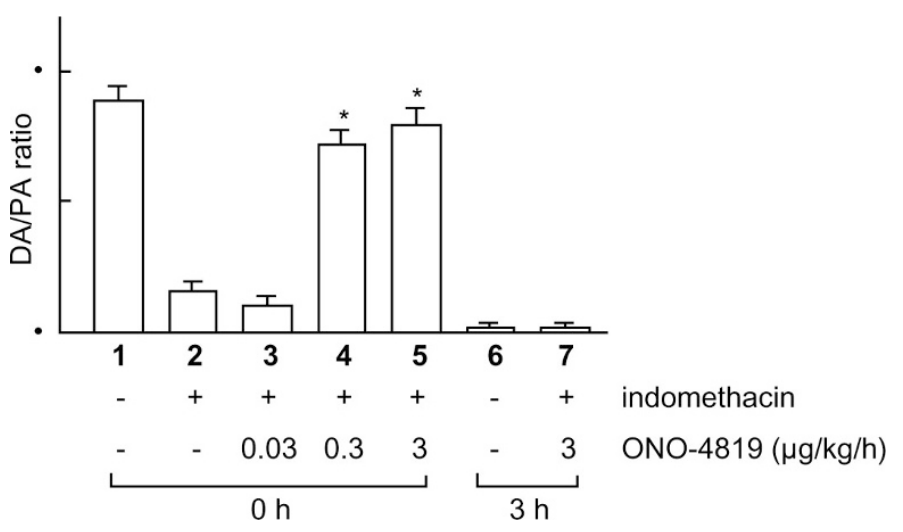

Figure 4. Prevention of indomethacin-induced DA closure at birth in vivo. Rat dams were infused with saline or ONO-4819 $(0.03,0.3$, or $3 \mu \mathrm{g} / \mathrm{kg}$ body weight $/ \mathrm{h}$ ) using s.c. implanted pumps and were administered indomethacin 10 $\mathrm{mg} / \mathrm{kg}$ body weight on the morning of $\mathrm{d} 21$ of gestation. Four hours later, pups were delivered through cesarean section to examine DA closure (DA/PA ratio) just after birth or $3 \mathrm{~h}$ after birth as described in "Methods." The administration of indomethacin resulted in DA closure (reduction of DA/PA ratio) and the treatment with ONO-4819 prevented the indomethacin-induced DA closure at birth but did not affect DA closure at $3 \mathrm{~h}$ after birth. Data were obtained from three independent experiments. An asterisk indicates significant $(p<0.01)$ increase in DA/PA ratio compared with that of the pups from dams with indomethacin alone at $0 \mathrm{~h}$.

that EP4 agonists did not induce any contraction of porcine uterine strips in vitro (22).

\section{DISCUSSION}

In the late gestational period, PG are one of the key players in initiating and completing parturition in mother $(1,2)$ and in fetus (3). During labor, PG that are released from placenta increase the intensity of uterine contraction and, consequently, exogenous PG have been used effectively to induce uterine contraction in inertia uteri. In the fetus, $\mathrm{PG}$, mainly $\mathrm{PGE}_{2}$, also participate in the regulation of circulatory change at birth, in 
Table 1. EP4 agonist induced no increase in rat uterine activity in vivo

\begin{tabular}{lccc}
\hline & $-10-0 \mathrm{~min}$ & $20-30 \mathrm{~min}$ & $50-60 \mathrm{~min}$ \\
\hline $\begin{array}{l}\text { Saline } \\
\text { ONO-4819 }\end{array}$ & 100 & $96.8 \pm 25.3$ & $103.2 \pm 6.9$ \\
$\quad 0.3 \mu \mathrm{g} / \mathrm{kg} / \mathrm{h}(5 \mathrm{ng} / \mathrm{kg} / \mathrm{min})$ & 100 & $90.2 \pm 14.4$ & $104.4 \pm 13.9$ \\
$\quad 3 \mu \mathrm{g} / \mathrm{kg} / \mathrm{h}(50 \mathrm{ng} / \mathrm{kg} / \mathrm{min})$ & 100 & $90.1 \pm 12.2$ & $100.6 \pm 13.1$ \\
Oxytocin $(20 \mathrm{mU} / \mathrm{kg} / \mathrm{min})$ & 100 & $184.6 \pm 14.5^{*}$ & $208.8 \pm 27.8^{*}$ \\
$\mathrm{PGF}_{2 \alpha}(20 \mu \mathrm{g} / \mathrm{kg} / \mathrm{min})$ & 100 & $168.4 \pm 14.8^{*}$ & $179.1 \pm 14.2^{*}$ \\
\hline
\end{tabular}

Uterine activity was monitored with a balloon catheter placed in the right uterine horn and was calculated and expressed as percentage of Montevideo units, as described in "Methods." The data are means \pm SEM from four dams.

* Significant $(p<0.01)$ increase in uterine activity compared with saline.

which the closure of DA is the biggest event (3). DA is kept open during pregnancy by circulating $\mathrm{PGE}_{2}$, probably via a cognate receptor, EP4 (5,7-10), and undergoes rapid closure in response to both a fall in $\mathrm{PGE}_{2}$ concentration by placental segregation and the action of constrictors induced by an increase in oxygen tension (3). This constriction may involve endothelin secretion and endothelin receptor type A stimulation $(15,23,24)$. In cases of heart anomalies in which survival depends on the patency of DA, $\mathrm{PGE}_{2}$ analogue has been used as a therapeutic intervention to keep the DA open.

NSAID such as indomethacin that block PG synthesis have been successfully used in the treatment of preterm labor (25). However, the use of indomethacin has been limited because of concern about adverse effects on the fetus, including constriction of the fetal DA in utero, which may lead to serious neonatal complications $(13,14)$. As COX-2 has been found to be responsible for PG release from the placenta during labor (26), COX-2 inhibitors were expected to prevent labor and avoid the adverse effects of nonselective COX inhibitors. However, it has been shown that the use of COX-2 inhibitors is not necessarily free of adverse effects on fetuses in animal models (27-31). In this study, we have used indomethacin, a nonselective inhibitor of COX subtypes, as an inducer of DA closure.

We investigated the effect of EP4 selective agonists $(19,32)$ on indomethacin-induced contraction of DA. In vitro, ONOAE1-437 relaxed indomethacin-induced as well as $\mathrm{O}_{2}$-induced DA contraction in a concentration-dependent manner (Figs. 1 and 2). In vivo, ONO-4819 prevented indomethacin-induced DA contraction in utero (Figs. $3 c$ and 4) but did not affect physiologic closure of DA after birth (Figs. $3 e$ and 4). There are two possible explanations for this difference in the DA dilating effects of ONO-4819 before and after birth. The first is the short half-life of ONO-4819 in the body, approximately 10-20 min (32), which prompts the clearance of the agonist from neonates after birth, preventing it from affecting the physiologic process of postnatal closure of DA. Under physiologic conditions, fetal $\mathrm{PGE}_{2}$ is supplied by the placenta to maintain fetal circulation and, therefore, the concentration of $\mathrm{PGE}_{2}$ in neonatal blood decreases rapidly after birth to facilitate postnatal DA closure (3). A similar decrease would be seen when the agonist is released from a capsule implanted in rat dams. In fact, an EP4 agonist prevented DA closure when administered directly to the neonate after birth (33). The second explanation is the postnatal rearrangement of EP recep- tors in DA. It has been reported that numbers of EP4 receptors in DA decrease after birth $(6,7)$. This would result in a postnatal reduction of the dilatory effect of EP4 agonists and is, therefore, consistent with our results.

EP4 plays a role in many physiologic processes (4) and its selective agonist has been shown to have several therapeutic possibilities $(19,32,34)$. The administration of ONO-4819 in rodents induces some acute side effects like diarrhea and hypotension, although they are seen only at higher doses than used in this report (19). COX inhibitor-induced premature closure of DA in utero not only causes deleterious pulmonary stress, which may underlie neonatal pulmonary dysfunction (12-14), but it also leads to incomplete but irreversible termination of DA remodeling, possibly resulting in persistent patent DA (35). Administration of EP4 agonist in addition to COX inhibitors might prevent adverse reactions on fetal DA without restricting the tocolytic effects of COX inhibitors.

\section{REFERENCES}

1. Gibb W, Challis JR 2002 Mechanisms of term and preterm birth. J Obstet Gynaecol Can 24:874-883

2. Sugimoto Y, Yamasaki A, Segi E, Tsuboi K, Aze Y, Nishimura T, Oida H, Yoshida N, Tanaka T, Katsuyama M, Hasumoto K, Murata T, Hirata M, Ushikubi F, Negishi M, Ichikawa A, Narumiya S 1997 Failure of parturition in mice lacking the prostaglandin F receptor. Science 277:681-683

3. Smith GC 1998 The pharmacology of the ductus arteriosus. Pharmacol Rev 50:35-58

4. Narumiya S, Sugimoto Y, Ushikubi F 1999 Prostanoid receptors: structures, properties, and functions. Physiol Rev 79:1193-1226

5. Smith GC, Coleman RA, McGrath JC 1994 Characterization of dilator prostanoid receptors in the fetal rabbit ductus arteriosus. J Pharmacol Exp Ther 271:390-396

6. Bhattacharya M, Asselin P, Hardy P, Guerguerian AM, Shichi H, Hou X, Varma DR, Bouayad A, Fouron JC, Clyman RI, Chemtob S 1999 Developmental changes in prostaglandin $\mathrm{E}(2)$ receptor subtypes in porcine ductus arteriosus. Possible contribution in altered responsiveness to prostaglandin $\mathrm{E}(2)$. Circulation 100:1751-1756

7. Bouayad A, Kajino H, Waleh N, Fouron JC, Andelfinger G, Varma DR, Skoll A, Vazquez A, Gobeil Jr FJ, Clyman RI, Chemtob S 2001 Characterization of PGE receptors in fetal and newborn lamb ductus arteriosus. Am J Physiol Heart Circ Physiol 280:H2342-H2349

8. Leonhardt A, Glaser A, Wegmann M, Schranz D, Seyberth H, Nusing R 2003 Expression of prostanoid receptors in human ductus arteriosus. Br J Pharmacol 138:655-659

9. Nguyen M, Camenisch T, Snouwaert JN, Hicks E, Coffman TM, Anderson PA, Malouf NN, Koller BH 1997 The prostaglandin receptor EP4 triggers remodelling of the cardiovascular system at birth. Nature 390:78-81

10. Segi E, Sugimoto Y, Yamasaki A, Aze Y, Oida H, Nishimura T, Murata T, Matsuoka T, Ushikubi F, Hirose M, Tanaka T, Yoshida N, Narumiya S, Ichikawa A 1998 Patent ductus arteriosus and neonatal death in prostaglandin receptor EP4-deficient mice. Biochem Biophys Res Commun 246:7-12

11. Macones GA, Marder SJ, Clothier B, Stamilio DM 2001 The controversy surrounding indomethacin for tocolysis. Am J Obstet Gynecol 184:264-272

12. Mushiake K, Motoyoshi F, Kinoshita Y, Nakagawa A, Ito M 2002 Severe heart failure due to ductal constriction caused by maternal indomethacin. Pediatr Int 44:174-176

13. Moise Jr KJ, Huhta JC, Sharif DS, Ou CN, Kirshon B, Wasserstrum N, Cano L 1988 Indomethacin in the treatment of premature labor. Effects on the fetal ductus arteriosus. N Engl J Med 319:327-331

14. Norton ME, Merrill J, Cooper BA, Kuller JA, Clyman RI 1993 Neonatal complications after the administration of indomethacin for preterm labor. N Engl J Med 329:1602-1607

15. Taniguchi T, Azuma H, Okada Y, Naiki H, Hollenberg MD, Muramatsu I 2001 Endothelin-1-endothelin receptor type A mediates closure of rat ductus arteriosus at birth. J Physiol 537:579-585

16. Shimokawa H, Yasutake H, Fujii K, Owada MK, Nakaike R, Fukumoto Y, Takayanagi T, Nagao T, Egashira K, Fujishima M, Takeshita A 1996 The importance of the hyperpolarizing mechanism increases as the vessel size decreases in endotheliumdependent relaxations in rat mesenteric circulation. J Cardiovasc Pharmacol 28:703-711

17. Hornblad PY, Larsson KS 1967 Studies on closure of the ductus arteriosus. I. Whole-body freezing as improvement of fixation procedures. Cardiology 51:231-241

18. Caldeyro-Barcia R, Sica-Blanco Y, Poseiro J, Panizza V, Mendez-Bauer C, Fielitz C, Alvarez H, Pose S, Hendricks CH 1957 A quantitative study of the action of synthetic oxytocin on the pregnant human uterus. J Pharmacol Exp Ther 121:18-31

19. Yoshida K, Oida H, Kobayashi T, Maruyama T, Tanaka M, Katayama T, Yamaguchi K, Segi E, Tsuboyama T, Matsushita M, Ito K, Ito Y, Sugimoto Y, Ushikubi F, Ohuchida S, Kondo K, Nakamura T, Narumiya S 2002 Stimulation of bone formation and prevention of bone loss by prostaglandin E EP4 receptor activation. Proc Natl Acad Sci U S A 99:4580-4585 
20. Coceani F, Olley PM, Bodach E 1975 Lamb ductus arteriosus: effect of prostaglandin synthesis inhibitors on the muscle tone and the response to prostaglandin E2. Prostaglandins 9:299-308

21. Clyman RI 1987 Ductus arteriosus: current theories of prenatal and postnatal regulation. Semin Perinatol 11:64-71

22. Cao J, Shayibuzhati M, Tajima T, Kitazawa T, Taneike T 2002 In vitro pharmacological characterization of the prostanoid receptor population in the non-pregnan porcine myometrium. Eur J Pharmacol 442:115-123

23. Coceani F, Kelsey L, Seidlitz E 1992 Evidence for an effector role of endothelin in closure of the ductus arteriosus at birth. Can J Physiol Pharmacol 70:1061-1064

24. Momma K, Nakanishi T, Imamura S 2003 Inhibition of in vivo constriction of fetal ductus arteriosus by endothelin receptor blockade in rats. Pediatr Res 53:479-485

25. Niebyl JR, Witter FR 1986 Neonatal outcome after indomethacin treatment for preterm labor. Am J Obstet Gynecol 155:747-749

26. Slater DM, Berger LC, Newton R, Moore GE, Bennett PR 1995 Expression of cyclooxygenase types 1 and 2 in human fetal membranes at term. Am J Obstet Gynecol 172:77-82

27. Clyman RI, Hardy P, Waleh N, Chen YQ, Mauray F, Fouron JC, Chemtob S 1999 Cyclooxygenase- 2 plays a significant role in regulating the tone of the fetal lamb ductus arteriosus. Am J Physiol 276:R913-R921

28. Coceani F, Ackerley C, Seidlitz E, Kelsey L 2001 Function of cyclo-oxygenase-1 and cyclo-oxygenase- 2 in the ductus arteriosus from foetal lamb: differential development and change by oxygen and endotoxin. Br J Pharmacol 132:241-251
29. Kajino H, Roman C, Clyman RI 2002 Renal effects of cyclooxygenase-2 inhibition in fetal lambs. Biol Neonate 82:257-262

30. Sakai M, Tanebe K, Sasaki Y, Momma K, Yoneda S, Saito S 2001 Evaluation of the tocolytic effect of a selective cyclooxygenase-2 inhibitor in a mouse model of lipopolysaccharide-induced preterm delivery. Mol Hum Reprod 7:595-602

31. Takahashi Y, Roman C, Chemtob S, Tse MM, Lin E, Heymann MA, Clyman RI 2000 Cyclooxygenase-2 inhibitors constrict the fetal lamb ductus arteriosus both in vitro and in vivo. Am J Physiol Regul Integr Comp Physiol 278:R1496-R1505

32. Kabashima K, Saji T, Murata T, Nagamachi M, Matsuoka T, Segi E, Tsuboi K, Sugimoto Y, Kobayashi T, Miyachi Y, Ichikawa A, Narumiya S 2000 The prostaglandin receptor EP4 suppresses colitis, mucosal damage and CD4 cell activation in the gut. J Clin Invest 109:883-893

33. Loftin CD, Trivedi DB, Langenbach R 2002 Cyclooxygenase-1-selective inhibition prolongs gestation in mice without adverse effects on the ductus arteriosus. J Clin Invest 110:549-557

34. Kasai K, Sato S, Suzuki K 2001 A novel prostaglandin E receptor subtype agonist, $0 \mathrm{~N} 0-4819$, attenuates acute experimental liver injury in rats. Hepatol Res 21:252260

35. Clyman RI, Chen YQ, Chemtob S, Mauray F, Kohl T, Varma DR, Roman C 2001 In utero remodeling of the fetal lamb ductus arteriosus: the role of antenatal indomethacin and avascular zone thickness on vasa vasorum proliferation, neointima formation, and cell death. Circulation 103:1806-1812 